\title{
'N EGGO VAN AFRIKANER-NASIONALISME: \\ 'N HOMILETIES-ANALITIESE TERUGBLIK OP \\ NEDERDUITSE GEREFORMEERDE PREDIKING UIT DIE JARE 1960 - $1980^{1}$
}

\author{
JH Cilliers \\ Departement PraktieseTeologie en Missiologie \\ Universiteit van Stellenbosch
}

\begin{abstract}
The period 1960 - 1980 marks a time of political, economical and social turmoil in South Africa. In this article fourteen sermons, reflecting the experience of threat and fear by a section of the white population, and the theological and homiletical effort to counteract this, are analyzed and evaluated. The sermons were published in the official magazine of the Dutch Reformed Church ("Die Kerkbode") and illustrates a general hermeneutical tendency. Firstly, to purpose analogies between the experiences of the Afrikaner and those of Israel. Secondly, to implement these analogies as a basis for moralistic preaching, and thirdly, to project guilt on to a caricaturized enemy. The paper concludes by suggesting the need for an ecumenical hermeneutics in which diverse perceptions of the Biblical message will/can be controlled and enriched.
\end{abstract}

\section{Inleiding}

Die herinnering aan die geskiedenis, ook die preekgeskiedenis, is 'n leermeester. Van leer uit dié geskiedenis is egter net sprake as nie net die ligpunte nie, maar ook die die skadu's daarin gesien en genoem word. In die herinnering aan dié geskiedenis wen ons verkondigingsversigtigheid én verkondigingsvrymoedigheid vir die toekoms, word ons begeester én tot skuldbelydenis gebring. Ook die preekdwalinge van gister moet en mag nie oorhaastig onder die mat gevee word nie. Onderdrukte herinnering wreek homself uiteindelik: dit verdwyn nie soos gister se sneeu wat smelt nie, maar kan ons uiteindelik versmoor (Bohren in voorwoord tot Richter-Böhne 1989). Indien ons in Suid-Afrika hierdie herinnering nie telkens lewend hou nie, loop ons gevaar om, ook in die prediking, in nuwe, of ten minste soortgelyke, of helaas erger, ideologiese strikke as in die verlede te trap. Hierdie artikel vorm 'n greep uit preke wat tydens 1960-1980 in die Nederduitse Gereformeerde Kerk gepreek is, en bevraagteken die gehalte van die teologie, maar ook die oorheersing van die ideologie daarin.

Die jare 1960 - 1980 kan breedweg beskryf word as 'n era in die Suid-Afrikaanse geskiedenis wat enersyds nog gekenmerk is deur na-oorlogse welvaart onder 'n groot deel van die blanke bevolking, andersyds deur 'n groeiende verhoudingsproblematiek en vervreemding tussen die verskillende bevolkingsgroepe. Die gebeure by Sharpeville (1960) vorm hierin 'n soort waterskeiding, en fokus die aandag van die wêreld op Suid-Afrika, met toenemende buitelandse isolasie en sanksies en binnelandse onrus en geweldpleging. (Vir 'n uitvoerige bespreking vergelyk Müller, CFJ 1980: 510-520). Die daaropvolgende

1. Verwerking van referaat gelewer by kongres ter viering van die 350 ste bestaansjaar van die Gereformeerde Kerke in Suid-Afrika - Stellenbosch, 7-10 April 2002. 
uittrede van Suid-Afrika uit die statebond (Mei 1961) veroorsaak die grootste ekonomiese krisis sedert die depressie van 1930-1932. 'n Kombinasie van politieke, ekonomiese en sosiale faktore het gevolglik meegebring dat 'n deel van veral die blanke volk hom in sy identiteit en voortbestaan bedreig begin voel het. Dit was 'n tyd van storm en drang op vele fronte, waarin die "blanke" kerk sy lidmate pastoraal wou begelei, ook in die prediking. Die preke wat hier aan die orde gestel word, moet in hierdie lig verstaan word, as preke wat die uitgesproke of onuitgesproke bedoeling gehad het om aktueel te wees, om 'n tydige woord vir die tyd te spreek. In 'n sin verklank dit die religieuse interpretasie van die noodtoestand van die "volk" ('n sleutelbegrip in die preke), verwoord dit die soeke na godsdienstige ankers, na troos, en kan as sodanig volksprediking genoem word.

Die breë koördinatesisteem waarbinne die preke geplaas kan word, is daarom enersyds die ervaring van bedreiging en angs, andersyds die intensie om die situasie van die blanke volk teologies te verklaar, en soos die analises aantoon, inderdaad te regverdig. Met behulp van linguistiese en teologiese kriteria word die hermeneutiese keuses en kortsluitings wat hieruit voortvloei beoordeel. Ek beperk my hier tot 'n bondige samevatting van die drie vernaamste hermeneutiese "tree" wat in die preke gegee word in hulle poging om Bybelse antwoorde op die situasie van die volk te bied. Dié treë is vasgestel deur ' $\mathrm{n}$ indringende analise van 14 preke. Vir die doel van hierdie artikel word nie uit al die preke aangehaal nie, maar slegs die basiese bevindinge weergegee, met enkele verwysings (vir 'n uitgebreide bespreking vgl. my God vir ons, 1994 Lux Verbi).

Die teologiese tradisie waarin die preke staan, is Gereformeerd: almal kom trouens uit Die Kerkbode, die amptelike blad van die Nederduitse Gereformeerde Kerk, wat tradisioneel beskou is as die grootste en invloedrykste kerk onder blanke Suid-Afrikaners. Hieruit maak ek 'n ekserp. Dit verteenwoordig geensins 'n statisties eksakte beeld van alle prediking in hierdie tydperk me. Die ondersoek wil nie sê: so is daar in Suid-Afrika, óf in Die Kerkbode, in hierdie jare gepreek nie. Maar wel: so is daar óók gepreek. Daar het natuurlik ook ander stemme opgeklink, stemme wat die "volksituasie" totaal anders verwoord het. Daar is ook preke - miskien die meerderheid - wat géén woord oor die situasie rep nie. Tog is dit opvallend dat die "bedreiging" in hierdie periode besonder sterk tot uiting kom, dat die vrees en onsekerheid 'n ongetwyfeld dringende karakter verkry. Hier is duidelike tekens dat jare lange tradisies onder skoot kom soos nooit tevore nie, dat dit inderdaad begin verbrokkel.

Met reg kan aanvaar word dat hierdie genre van prediking 'n noemenswaardige invloed uitgeoefen het op die denkklimaat, nie alleen van die plaaslike gemeentes nie, maar ook van die breër bevolking onder wie die Nederduitse Gereformeerde Kerk werksaam was en is. Die rol van die prediking as meningsvormer moet nie oorskat, maar ook nie onderskat word nie, veral as dit handel oor die legitimering en bestendiging van bestaande godsdienstige en sosiale profiele. Die prediking is dikwels slegs 'n spieëlbeeld van die gemeenskap wat dit bedien (Müller, BA 1987: 43-44).

Daarom is dit te verstane dat, alhoewel die preke oor verskillende Bybelse tekste handel, die hermeneuties-bepaalde grondstruktuur, op enkele beklemtonings na, presies dieselfde is. In al die preke vorm hierdie struktuur 'n hegte eenheid waarin al die elemente wesenlik saamhang en mekaar bevestig. Die leser sou dieselfde struktuur waarskynlik ook in ander periodes en in ander volkspreke kon herken. Trouens, dit is moontlik dat ons hier nie met 'n blote Nederduits Gereformeerde of Suid-Afrikaanse fenomeen te make het nie (vgl. Cilliers 1996:15 e.v.). Die situasies van angs waarin predikers en gemeentes hulleself bevind, mag van tyd tot tyd verskil, mag totaal ander trekke vertoon, maar die hermeneutiese weg wat gevolg word om die angs te oorwin, is stereotiep. Die basis van 14 
preke en die beperking tot 1960 - 1980 bied 'n greep op 'n wyer verskynsel.

In die ondersoek maak ek gebruik van die analitiese metode wat deur die Switserse teoloog Rudolf Bohren en die Duitse skrywer Gerd Debus aan die Universiteit van Heidelberg in Duitsland ontwikkel is. (Bondig saamgevat in Bohren 1989: 55-61). Dit het ontstaan uit die noukeurige lees ("close reading") van letterlik duisende preke, en neem as uitgangspunt die reg en mag van 'n gemeente om as ecclesia completa die prediking krities te beaam. Die bedoeling is dat die metode 'n beoordelingshulp vir gemeentes moet wees (vergelyk Cilliers 1992: 383-389). Dit word tans toegepas en verfyn deur die Ekumeniese Vereniging vir die bevordering van die prediking, wat sy setel in Heidelberg het en oor 'n preekbank van meer as 20000 preke uit 'n breë spektrum van teologiese en kerklike konfessies beskik, onder andere uit die Tweede Wêreldoorlog, asook die na-oorlogse periode waarin aangeleenthede soos skuld en restitusie aan die orde gestel moes word. Dit is dus 'n metode wat gegroei het uit 'n sensitiwiteit vir die geskiedenis van die prediking én na aan die praktyk wil beweeg, 'n stuk geïntegreerde praktiese teologie in eie reg.

In samewerking met die Vereniging is die genoemde preke tydens 10 byeenkomste geanaliseer. Die analitiese span het bestaan uit teoloë en predikante van die LuthersEvangelies en Rooms-Katolieke kerke, asook 'n aantal doktorandi en leke-predikers. Die belangrikste bevindinge van hierdie sessies, asook van talle persoonlike gesprekke met lede van die Vereniging, word hier bondig weergegee, en bied dus 'n breër, ekumeniese visie op dié spesifieke preekvorm.

Formeel bestaan die metode uit ' $\mathrm{n}$ aantal analitiese sowel as sintetiese stappe. Enersyds word die preekteks in extenso ondersoek, word sy onderskeie bestanddele (woorde, sinne, paragrawe) linguisties nagegaan sodat die oppervlakstruktuur duidelik word. Andersyds word die onderlinge verhoudinge tussen die linguistiese bestanddele vasgestel, ten einde die grond-motiewe van die preek aan die lig te laat kom. Dié motiewe vorm gesamentlik die dieptestruktuur van die preek. Die wisselwerking tussen die oppervlak- en die dieptestrukture bied die moontlikheid om die preek teologies te interpreteer. Teks-immanente analise en teologiese interpretasie vorm dan die instrumentarium waarmee die preek as linguistiese en teologiese eenheid gehoor word. Die homileties-teologiese raamwerk waarbinne dit geskied, is hoofsaaklik die preekleer van Rudolf Bohren, wat onder andere sterk rus op reformatoriese insigte in die prediking (vergelyk Bohren 1971: 3 e.v.).

Die metode vra na die kwaliteit van tekste, en gee nie voor om alwetend oor die werklike werking van preke te wees nie. Die Gees is immers nie gebonde aan metodes, retoriek of letters op papier me. Die Gees werk. Hierin lê die grense, maar ook belofte van so 'n ondersoek. Dit neem predikers op hulle woord, in 'n poging om hom of haar te verstaan, beter te verstaan as wat hulle hulself verstaan het. Dit wil in hierdie geval volkspreke teologies verstaan. Daarom vra dit na die innerlike logika van die preke, soos dit uit elke konkrete preekteks blyk, en voer dit tot sy uiterste konsekwensies; tree dit die preek binne deur die poort van die oppervlakstruktuur en soek die dieptestruktuur, die deurslaggewende samehange, om die werklike beweegredes en motiewe te begryp.

Ook hier word nie voorgegee dat die metode oor suiwere objektiwiteit beskik nie. Tekste is, soos mense, 'n geheim, 'n lewende verskynsel met vele fasette. Ons weet nie alles van tekste nie en ons weet nie alles van mense nie. Daarom onderskei die metode tussen analise en interpretasie, maar skei dit nie. Elke analise is alreeds ' $n$ interpretasie, en dus kontekstueel. Dit is bedoel as 'n navraag van broers en susters aan broers en susters, as 'n poging om te hoor, en te hoor of ander ook só hoor, as 'n gesprek oor die prediking, en dus oor die Woord van God self. 


\section{Die eerste hermeneutiese tree: terug in en uit die geskiedenis}

Die mees algemene, en inderdaad deurslaggewende struktuur vir die verstaan van die geanaliseerde preke, is die situasie-analogie wat tussen die huidige tyd en die Bybelse tyd veronderstel word. Die basiese uitgangspunt hiervan is: wat destyds gegeld het, geld ook vir ons; wat destyds deur God gedoen of van mense gevra is, geld ook vir ons tyd. Toegepas op die enkeling lui dit: soos dit met hierdie of daardie Bybelse figure daaraan toegegaan het, so gebeur dit ook met die mense van vandag in hulle ontmoeting met God (Josuttis 1966: 23).

Die skarniere waarop so 'n analogielegging (Josuttis: Analogieschematismus) draai, is daarom dikwels uitdrukkings soos:

"Só, presies só, gaan dit ook vandag".

"Ons is ook ...".

"Net so het ons volk hom ook ...".

"Soos die Joodse volk, het ook ons volk ...".

"Ons tye en omstandighede is nie baie anders as in die tyd van Noag nie."

Die bedoeling is om te sê: wat ons nou ervaar is nie uniek nie, ander het dit alreeds ervaar. Dit wil toon dat die onderskeie tye in werklikheid identies is; om so die eie situasie en tyd binne heilshistoriese perspektief te probeer plaas. In die benutting van die analogieskematisme word geborgenheid in 'n tyd van nood gesoek. Die pastorale motief is stabilisering in 'n tyd van onsekerheid. Die grondliggende veronderstelling daarvan is dat die aktualiteit van die Woord van God afhang van die parallelisme van heilshistories en histories vergelykbare situasies en die konformiteit van algemeen antropologiese bestaanstrukture. Daarom moet daar in die prediking gesoek word na ooreenkomste, identifikasies, vergelykings en voorbeelde om as troos en appèl vir die hede te dien.

Sonder om hier in te gaan op die hele problematiek rondom eksemplariese prediking (vir 'n uitgebreide bespreking vergelyk Greidanus 1970: 56-120), is dit duidelik dat dié analogieskematisme unieke historiese situasies by wyse van eenlynige analogieë oorvereenvoudig, dat dit die meerdimensionaliteit van die heilsgeskiedenis soos dit in die Skrif geboekstaaf word, tot 'n enkele punt of hoogstens 'n aantal aspekte reduseer ten einde dit met bepaalde oogmerke na die huidige situasie van die "volk" oor te dra. 'n Bestudering van die analogieskematisme, soos dit in die preke funksioneer, toon dat 'n enkele aspek van die vertelde heilswerklikheid gefikseer en geabstraheer word, normaalweg met reduksie van die Bybelse horison, met die doel om die huidige situasie te regverdig. So word Noag byvoorbeeld 'n vleklose argetipe waarop die volk homself moet modelleer, word Noag en die volk in feite identies, terwyl die vyande van die volk geïdentifiseer word met die verrotte mensdom van Noag se tyd.

Die implementering van so 'n analogieskematisme het deurslaggewende teologiese gevolge in die preke. Dit hef naamlik die spanning, die dialektiek op wat die verhouding tussen God en die geskiedenis kenmerk. In plaas daarvan dat God verkondig word as die Een wat onderskeidelik in die verlede, hede en toekoms handel (soos Hy wil), word Hy in die onderskeie tye vasgelê. By implikasie word Hy in twee gedeel. Enersyds word Hy in 'n situasie van destyds vasgeskryf (byvoorbeeld 300 v.C.); andersyds word Hy in die hede vasgepreek. Streng genome kán Hy nie nuut en anders handel nie: deurdat Hy so in die geskiedenis vasgeskryf en vasgepreek word, word Hy uit die geskiedenis weggeneem, word sy heerskappy oor die geskiedenis Hom ontneem. Daarmee word Hy 'n bo-tydelike prinsiep. 
Wesenlik is die analogieskematisme 'n manier om aan die tyd, en die voortgang van die tyd en van God se selfopenbaring in die tyd te ontsnap; dit is 'n teruggreep op die geskiedenis om die werklikhede van die hede en die toekoms te vermy. Dit wil die tyd arresteer en die geskiedenis reproduseer. In hierdie arrestasie en reproduksie word God vergelykbaar en onwerksaam. God is egter presies die teenoorgestelde: Hy is die onvergelykbare werksame (HW Wolff 1969: 400 e.v.).

In die analogieskematisme ontstaan ' $n$ vaste beeld van die geskiedenis, van die mens en God. 'n Eenmalige situasie en gebeure word oorvereenvoudig, gefikseer en God daarby ingesluit. Dit geskied deur die interpretasie, die beeld wat geformeer word van die verlede en pas gemaak word op die hede, en andersom. Omdat die beelde van verlede en hede op mekaar moet pas, identies moet wees, word beide vals, dit wil sê vind werklikheidsverlies van sowel verlede as hede plaas (vergelyk Pressel 1967: 352). In hulle plek tree 'n beeld na vore, 'n vasgelegde en daarom valse beeld.

Beeldvorming van dié aard verdring God, en skep 'n vakuum. Die beeld tree dan self dié vakuum binne as surrogaat vir die lewende God, en verkry so die gestalte van 'n spesifieke soort mite (vir uitgebreide bespreking vergelyk Slök 1960: 1263 e.v.). Dié verskynsel is kompleks van aard en kan byvoorbeeld onder filosofiese, filosofiessemiotiese, sosiologiese en godsdiens-wetenskaplike gesigspunte beskryf word. In hierdie ondersoek maak ek veral gebruik van die taalfilosofiese bevindinge van Roland Barthes (1964: 110 e.v.) in verband met die mite. Barthes het die ontstaan en die ontwikkeling van alledaagse mites linguisties nagevors, en tot die gevolgtrekking gekom dat hierdie vorm van mite geskiedenis wesenlik anders interpreteer en vertel as wat die historiese wetenskap dit in geskiedskrywing doen. Terwyl die ideaal van laasgenoemde die verstaan van die geskiedenis in al sy samehange is, verander die mite geskiedenis in natuur (1964: 113). Enkele gesigspunte word uit die unieke inter-relasie van historiese gebeurtenisse geabstraheer en in 'n herhaalbare patroon verander. Dié patroon of prinsiep word aangewend met ' $\mathrm{n}$ spesifieke doelwit, byvoorbeeld die regverdiging van sosiale, politieke of ideologiese strukture.

Die analogieskematisme, wat ook 'n tydlose sisteem wil skep, is 'n vorm van mitebou. Die mite, of vaste beeld van die geskiedenis wat die heilsgeskiedenis en gevolglik die God van die heilsgeskiedenis verdring en vervang, is die volksgeskiedenis soos dit in die preke gereflekteer word en waarin die volksidentiteit gevind word. Die bedoeling is dat die volksgeskiedenis ewige, onveranderlike waarde moet kry. Dit vind plaas deur 'n "uitruil" van geskiedenisse, 'n identifikasie daarvan: in die plek van die heilsgeskiedenis kom die volksgeskiedenis, en andersom. Volksgeskiedenis word heilige geskiedenis, word openbaring - van die mite. In die proses word God nie alleen bokant die geskiedenis uitgelig nie, maar tegelyk ook an die volk se geskiedenis vasgebind in die sin dat Hy die geskiedenis moet legitimeer. Hierdie uitruil van geskiedenisse is moontlik - in terme van Barthes - omdat die mite geskiedenis in natuur verander, omdat dit tydlose, algemeen geldige, wetmatige aspekte van die geskiedenis met behulp van abstrahering, reduksie en analogie na vore bring en verabsoluteer (1964: 113 e.v.).

Dié volkseiendomlike "heilsgeskiedenis" word feitlik sonder uitsondering in die geanaliseerde preke vertel en ò̀rvertel. Dit vorm die onaantasbare, vasstaande vertrekpunt en veronderstelling. Dit geskied enersyds om die "volk" aan sy verlede te herinner, andersyds moet dit as stukrag met die oog op die toekoms dien. Die belangrikste funksie daarvan is egter om as apologie, as justificatio populi te dien in 'n tyd van bedreiging en angs. Dit vorm die verwysingsraamwerk en ankerpunt vir die stabilisering van die volksidentiteit in die hede. Dit is die uiteindelike doelwit van die analogieskematisme. 


\section{Die tweede hermeneutiese tree: na binne, tot in die potensiaal van die volksiel}

In die proses van mitebou bedien die analogieskematisme homself van 'n aantal meganismes, wat in die reël betroubare tekens en konsekwente begeleiers van die skematisme is, en tot die wese van die mite behoort. Die analogieskematisme gaan byvoorbeeld deurgaans oor in imperatiwiese redevorme. Tussen die analogieskematisme, die mite en hierdie redevorme is 'n logiese en toetsbare verband. Trouens, die imperatiewe struktuur word alreeds in die analogieskematisme gegéé. Die optrede of situasies van mense wat in die Bybelse tyd die veronderstelling vir die verkondiging was, word in die hede die voorwaarde daarvoor (Josuttis 1966:24). Wat voorheen 'n woord oor God se handelinge in die geskiedenis was, word 'n woord oor mense se handelinge in die geskiedenis, en wel so dat dit 'n oproep aan die huidige hoorders vorm om dienooreenkomstig te handel. Teologiese uitsprake word etiese appèlle; bepaalde situasies word bepalende situasies. byvoorbeeld:

"Vir óns moet die oorgang van die óue na die núwe jaar ook beteken wat Ahawa vir Esra en sy reisgenote beteken het".

"Soos Nehemia moet elke vader en moeder, elke jongmens en kind, elke volksleier en opvoeder, elke leraar en prediker, die hand van God op hom voel".

Eers projekteer die analogieskematisme 'n valse beeld op die werklikheid, daarna roep dit op tot die instandhouding van hierdie beeld. Die beeld vorm die norma normans vir handeling, en die beeld verplig tot handeling. Daarom is dit verstaanbaar dat die analogieskematisme hoofsaaklik in konjunktiewe spraakvorme te voorskyn tree: oor werklikhede word as moontlikhede gepraat; in die plek van werklikhede word moontlikhede gepostuleer in die irrealis. Hierdie postulate staan egter ook onder 'n voorwaarde: wanneer mense sekere handelinge verrig, sal dit blyk dat die mities gepostuleerde en irreële beeld van die geskiedenis 'n "werklikheid" kan word, dat dit "waar" en "normatief" is; sal die huidige tyd inderdaad ooreenstem met die vergange tyd, en andersom. Daarom word die conjunctivus irrealis, ook wanneer dit nie eksplisiet funksioneer nie, sigbaar in voorwaardelike sinskonstruksies, soos: "wanneer ... dan”; “as ... dan”, ensovoorts. Op hierdie wyse word oor heilshistoriese werklikhede, oor die werklikheid van God self gepraat. Omdat God in die gepostuleerde beeld van die geskiedenis opgesluit is, word ook oor Hom in irreële, voorwaardelike terme gepraat.

Die sterk imperatiwiese karakter van die preke bring die vraagstuk na die verhouding tussen wet en evangelie na vore. Hierdie verhouding is 'n komplekse saak, en kan nie hier in al sy fasette behandel word me. Die korrekte onderskeiding van wet en evangelie behoort veral tot die regte prediking. Om evangelie en wet te onderskei, beteken om 'n prediker te word. 'n Mens kan dié verhouding net preek (Iwand 1964:13).

Uit die preekanalises blyk dit dat die wesenlike verband tussen wet en evangelie in die volkspreke prinsipieel verbreek word. Terwyl daar 'n oorvloed van volksappèlle is, is die gebrek aan konkrete toeseggings, aan die verkondiging van die vrye genade van God alleen opvallend. Die bedreigde situasie van die volk maak die aartsversoeking om die evangelie vir 'n wettiese wet, en, soos die analises aantoon, veral vir 'n wettiese evangelie te verruil, blykbaar nog meer onweerstaanbaar. Die evangelie self word in sy hart aangetas. Die "swakheid" daarvan bied oënskynlik nie oplossings vir 'n situasie wat daadkrag vra nie; daarom word gegryp na 'n wet wat dinge meer manipuleerbaar moet maak. Dit lyk tog meer "logies", bied meer "handvatsels" op die moeilike tyd. Hierdeur moet die angs teëgewerk word.

Alle vorme van wettisisme veronderstel 'n mens met potensiaal, 'n mens wat deur sy of 
haar optrede self die sonde skadeloos kan stel. Wettisisme neem as uitgangspunt nie alleen 'n irreële, afwesige God nie (die gevolg van die eerste hermeneutiese tree), maar ook 'n vitale, intakte mens, 'n homo intactus, in plaas van 'n homo peccator. Wettisisme lei in hierdie geval tot 'n verkapte antropologie. Dit vind sy teelaarde in 'n gebrekkige hamartologie (sondeleer) én 'n "teologie" van die triomf - van die mens. Wesenlik is dit liberaal: op die oog af lyk sulke preke "korrek"; die dieperliggende basis daarvan is egter nie die evangelie nie, maar die mens. $\mathrm{Al}$ is die mens ook vroom.

Die potensiaal van die mens kom in die preke veral op twee wyses na vore. Eerstens is daar preke wat in hulle oproepe sterk individualistiese trekke vertoon. Die verleentheid met die toestand van die volk bring blykbaar mee dat die volk as sodanig nie meer met die instandhouding van die tradisies (mite/s) vertrou kan word nie, en individue die situasie nou moet beredder. Tweedens is daar die neiging - by die meerderheid van die preke - om oproepe te doen op grond van die veronderstelde religieuse potensiaal van die volk, 'n volk met "tradisies en sedes" wat van sò 'n kwaliteit is dat die hele wêreld 'n "aanslag" teen dié volk loods - en wat op grond van dié "tradisies en sedes" in staat is of moet wees om die aanslag te oorkom.

Hierdie hermeneutiese tree tot in die potensiaal van die volksiel het weereens diepgaande teologiese gevolge. Eerstens word "Kerk" en "volk" uitruilbare terme, en vir alle praktiese doeleindes, identies. 'n Ekklesiologiese degradering vind plaas, in dié sin dat die kerk nie meer as skepping van God se Woord (creatura verbi) figureer nie, maar as skepping van òf die individu òf die volk, 'n eie produk (creatura ipsissima). Die grondreël van dié verkapte ekklesiologie lui: God is pro nobis, as ons pro patria is. Andersins nie.

Tweedens vind ' $n$ degradering van die Christologie plaas, in dié sin dat Christus in wese vervang word deur 'n homo intactus. Die Christologie word verantropologiseer. In hierdie opsig stem die tweede hermeneutiese tree presies ooreen met die eerste, en bevestig die twee mekaar: die onthistorisering van God blyk ook uit die vervanging van Christus deur intakte mense - iets wat Luther niks minder nie as 'n annihilatio Dei genoem het. Die Naam van Christus kom wel formeel voor, maar funksioneer in feite as 'n addendum, nie as grondliggende hermeneutiese faktor nie. Wettiese preke word trouens dikwels gekenmerk deur 'n oorvloed Christologiese sinne wat dieperliggende teologiese gebreke retories moet versluier (Josuttis 1966: 61 e.v.). Die evangelie self, dit wil sê die genade, word metodologies en sintakties in die preke uitgesluit.

\section{Die derde hermeneutiese tree: na buite, met die projeksie van skuld}

Die analogieskematisme vorm ' $n$ irreële beeld van die geskiedenis, én roep mense op om as irreële (dit is onskuldige) mense hierdie beeld in stand te hou. Eén van die maniere waarop dié mense op die been gebring en gehou word, is deur die projeksie van skuld op ander mense. Die eerste tree was ' $n$ tree terug in en uit die geskiedenis, tot in die tydloosheid van die mite; die tweede 'n tree na binne, tot in die potensiaal van die volksiel; die derde nou 'n tree na buite, met die projeksie van skuld vanaf die "binnegroep" (die volk) op die "buitegroep" (die vyande). Met hierdie projeksie van skuld moet die onskuld van die volk deurlopend bestendig word. Dis immers hierdie volk wat, in die geval van die preke, die analogieskematisme waar moet maak, en so die mite moet laat funksioneer. Dié projeksie van skuld is in ' $n$ bepaalde sin die punt van die ysberg. Hier blyk die dieperliggende aard van die mite op sy duidelikste, breek dit openlik deur die oppervlakstruktuur van die teks, en bevestig dit op 'n gekonsentreerde wyse die voorafgaande analises.

Enersyds word die homo intactus dus as 'n vitale, aktiewe mens beskou; andersyds, as dit kom by die aandadigheid aan dit wat in die geskiedenis verkeerd is, as 'n passiewe, 
uitgelewerde mens. Die vyand word deurgaans as die aktiewe bejeën, maar dan in die negatiewe, in die skuldige sin van die woord. Hierdie aktief-passiewe dualisme vorm 'n vaste bestanddeel in elke "situasie-analise" wat gemaak word: die voortbestaan en identiteit van die volk is op die spel, een van sy grootste krisisure het oor hom gekom - maar is nie deur hom teweeggebring nie. Sinne soos die volgende illustreer dié dualisme:

"Die Afrikanervolk verkeer voorwaar in 'n onbenydenswaardige posisie. Ons is by uitnemendheid die skyf van die haatpropaganda in haas elke land ter wêreld ... Ons moet ontwapen word om dan daarna met die minste moeite soos slagskape na die slagpale gesleep te word".

Dié polarisering deur middel van spraakvorme en beelde bring mee dat daar eintlik twee adressante in die preke is: die gemeente en die teenstanders wat indirek aangespreek word. Die gemeente word die getuie van die openlike protes teen die teenstanders (vergelyk Richter-Böhne 1989:123). In die proses word afstand tussen die gemeente en die indirek aangespreektes geskep. Deurdat uiters terughoudend oor eie aandadigheid aan die "probleem" gepraat word en uiters ekspressief oor die aandadigheid van die ander, word 'n vyandsbeeld van die "ander" aan die gemeente omlyn. Daar kan géén gemeenskap, géén eenheid wees tussen dié wat naby en dié wat ver is nie. Die eerste funksie van dié projeksie van skuld is selfregverdiging, in die sin dat eie identiteit positief bevestig word deur ' $n$ negatiewe afgrensing van die ander, die vyand. In die mate waarin die ander gestigmatiseer word as vyande van God, word die volk gestabiliseer as vriende van God; die polemiek teen die ander versterk die apologie vir die eie. Ook hier blyk die geslote, verkapte ekklesiologie: dit benodig die "vyand" as 'n noodsaaklike element in die prediking. In dié opsig bedreig die vyand nie net nie, maar bevestig hy ook.

In die lig van die Suid-Afrikaanse werklikheid (dit wat die mite juis wil uitwis!) is die preke verontskuldigend, is dit gepreekte onboetvaardigheid. Dit kàn eintlik nie anders nie: die volk moet immers die "belofte" van die mite dra, en durf as sodanig geen skuld hê nie. Om skuld te verkondig of te bely is om in die hande van die vyand te speel. Wanneer daar, benewens die projeksie daarvan, wél oor sonde gepraat word, is dit òf in die algemeen, òf binne die konteks van sekere volksideale. Sonde word verstaan as die verval van die volk, as die versuim om mee te werk aan die volksbestaan en -identiteit. Sonde is om nie meer die "God van die vadere" te dien nie. Sonde is om die tradisie te verbreek. Sonde is om die mite te minag.

Die oproep tot bekering en boetedoening is daarom ook meestal 'n oproep om terug te keer tot 'n algemene, burgerlike moraal (vergelyk Bohren 1983:347). Robert Carroll is van mening dat fundamentalisme in sy diepste wese 'n beskerming van middelklaswaardes is. Dìs volgens hom die ideologie wat die eksegese en die hermeneutiek "rig" (1991:35 e.v.). Enigiets wat teen dié waardes indruis, word as sonde beskou; enigeen wat tot dié waardes terugkeer, word as berouvol bejeën. Die gevolg is dat die middelklaswaardes uiteindelik die finale regter word oor die korrekte interpretasie van God se geopenbaarde wil in die Bybel (vergelyk ook Deist 1990:133). Boetedoening word in dié sin verstaan as die aktiewe bemoeienis van andersins vroom mense om hulle morele tekortkominge self op te vul. Op hierdie wyse moet God gunstig gestem word en die voortbestaan van die volk verseker word.

Dié boetedoening sou daarom ook op 'n ander vlak verstaan kon word. In die sestigerjare, maar veral die sewentigerjare met die toenemende isolasie van Suid-Afrika en die Nederduitse Gereformeerde Kerk het 'n soort apokaliptiese mentaliteit ontwikkel waarin alle "aanslae" as Goddelike loutering geïnterpreteer is. Loutering veronderstel nie skuld nie, maar toetsing, in die sin van: "Hy wat volhard, sal gered word". Dit is dus nie meer nodig om oor skuld te praat nie, slegs oor volharding, want wie nie volhard nie, word deel van die mense wat gestraf word, word deel van die vyand. 
By die meeste preke is die verband tussen die bedreiging en die oordeel van God geheel en al afwesig. Daar word trouens van dié verband weggestaan. Die projeksie van skuld vervul hierin - ek interpreteer - ' $\mathrm{n}$ tweede funksie: nie alleen is dit ' $\mathrm{n}$ selfregverdigingsakte nie, maar dit dien as ontsnappingsroete uit die oordeel van God, 'n wegvlug daarvan. Die sonde, en dus ook die oordeel van God, word by die adres van die ander gelaat. Die volk word onskuldig en oordeelsvry gehòù. Dit is heel logies: omdat die leer van die regverdiging uit genade in sy kern aangetas word (vergelyk die tweede hermeneutiese tree), word God nie meer as komende Regter verkondig nie. Trouens, enige vorm van oordeel oor die volk, selfs net tekens daarvan wat as vooruitgrype op die eindoordeel in die geskiedenis sou kon voorkom, word verswyg. Die geslote sisteem van die mite kan immers geen invloede van buite duld nie, mag nie gerelativeer word nie, maar moet self die norm vir die oordeel bly. Tussen die oordeel van God en die mite mag geen kritiese distansie toegelaat word nie.

In die preke word God nie alleen uit die geskiedenis gehaal en sy teenwoordigheid en werksaamheid in die hede vervang met die teenwoordigheid en werksaamheid van intakte mense nie, maar word Hy ook uit die toekoms weggeneem. Die preke is prinsipieel oneskatologies. Christus kom nie meer om te oordeel oor die lewendes en die dooies nie. Mense kom. Mense moet die toekoms verseker. Mense neem die oordeel oor - oor ander.

\section{Slotsom: wat moet ons uit dié preekgeskiedenis leer?}

Uit bogenoemde drie hermeneutiese treë blyk dit dat die prediking misverstaan word as 'n middel om bepaalde volksideale te realiseer en te verdiep. Na my mening word veral dit deur die analises aangetoon: die prediking funksioneer nie meer as 'n vreemde, kritiese en daarom verlossende woord van God in die volk se situasie nie, maar bloot as 'n sanksionerende en stabiliserende woord. Die mite(s) van die volk neem die prediking sò in diens dat die binnegroep in hulle oortuiginge bevestig en versterk word in hulle teenstelling met die buitegroep. Die prediking is in dié sin inderdaad 'n goeie spieëlbeeld, 'n eggo van die samelewing - van die volk. Dit vorm deel van die openbare diskoers wat hom in hierdie era in politieke, sosiale, kulturele en kerklike debatte afgespeel het. Klaarblyklik is die preke as spraakgebeure so ingebed in die eietydse spreekwyse en -inhoude, word dit so bepaal deur die heersende sosiale, ekonomiese en politieke clichés en retoriek, kortom, deur die breër netwerk van die sosiale taal van die dag, spesifiek dié van Afrikaner-nasionalisme, dat dit geheel en al daardeur ingesluk word. Die preke ontkom na my mening nie aan die suigkrag van bepaalde volksmites nie, slaag nie daarin om vernuwend en veranderend op die samelewing van die volk in te werk nie. Inteendeel, die ironie is dit: die preke wil die evangelie vir die situasie ontsluit, maar sluit die evangelie in die situasie op.

Hiervoor moet ons begrip hê. Ons leef immers almal binne kontekstuele raamwerke, met eensydige perspektiewe en eksklusiewe mites. Dit is uiters moeilik, selfs onmoontlik om uit hierdie raamwerke te tree en "objektief" en "neutraal" daaroor te oordeel. Hier moet dit dus gesê word: die predikers worstel ten minste nog met die Bybel, vra ten minste nog na "God" binne hulle raamwerk. Slegs mense in wie die Gees werk, doen dit. Daarom moet die huidige preekgeslag krities-pastoraal teenoor hulle as preekvaders wees: omdat hulle ons broers is, en ons hulle ook sò ervaar.

Die vraag is nou: kan ons hoegenaamd uit die isolasie, uit die greep van ons mites losbreek? Hierop is daar geen pasklare antwoorde nie. Geen resep of "wet" kan dit waarborg nie. Die prediking bly 'n waagstuk. Ons kan egter ten minste bewus gemaak word, sensitief gemaak word vir die invloede wat op die prediking inwerk. Dis 'n begin.

Wat kan ons dus uit hierdie stuk preekgeskiedenis leer? In die lig van die analises gesien, sou mens byvoorbeeld kon sê: 
- dat ons uiters versigtig met heilshistoriese analogieë moet omgaan, veral as dié analogieë ingespan word om historiese of huidige situasies te regverdig of te vergoddelik (vergelyk Marsch 1964:533). Die evangelie ontgoddelik eerder die werklikheid as werklikheid voor God.

- dat die neiging om mense in eksklusiewe kompartemente van "goed" en "kwaad" of "uitverkore" en "boos" te verdeel, met die gepaardgaande projeksie van skuld vanaf jouself na ander, raakgesien en met die taal van skuldverbondenheid vervang moet word, 'n taal wat die sterwende seun Markel byvoorbeeld in Dostojewski se roman Die Broers Karamasow praat as hy vir sy moeder sê: "Ons is voor almal in alles skuldig, en ek, ja ék, meer as almal".

- dat die aanspraak dat ek of ons in besit van die absolute waarheid is, plek moet maak vir 'n ruimer visie, 'n openheid vir die meerkantigheid van die waarheid. Die selftoeëiening van ontologiese outoriteit en heilige onaanvegbaarheid moet die gevaarklokke laat klingel!

- dat enige relasie van dominansie wat deur taal bestendig word, ideologies-krities aan die lig gebring moet word deur veral te let op die neiging van ideologieë om hulself sò in die taal te versteek, dat eie skuld verborge bly. Kortom, dat die destruktiewe en dehumaniserende elemente van mites betyds onderskei moet word (vergelyk Adonis/Smit 1991:28-30 oor die analise van Grabner-Haider).

Maar hoe? Deur terug te keer na die Woord met 'n openheid vir die onuitputlike interpretasiemoontlikhede daarvan? Ja. Ons is immers Gereformeerdes wat bely: sola scriptura. Hierin lê waarskynlik die diepste tragedie en hartseer van hierdie tipe volksprediking: dit was - miskien teen die bedoeling in - nie meer Skrifprediking nie. Volkspreke van hierdie aard waarsku ons om steeds - as Gereformeerdes - hard aan die teks te bly (Cilliers 1998:69; ook 2000: 121-122). Dit ìs so. Maar om net te sê dat ons moet terugkeer na die Woord, is nie genoeg nie. Ons lees dikwels die Woord net sò dat ons in ons oortuiginge versterk word. Dis ons dilemma. Ons lees die Bybel dikwels vanuit lynreg teenoorgestelde leefwêrelde, met teenstrydige interpretatiewe raamwerke, perspektiewe, kollektiewe "stories" en mites.

Hiervan moet ons bevry word. Na my mening kàn so 'n bevryding plaasvind, en wel binne die ruimte van die ekumene, van die kerk in die breedste sin van die woord. Die kerk as una sancta catholica is immers God se gawe aan ons. Binne hierdie gemeenskap is daar verrykende en kontrolerende kragte werksaam soos nêrens elders nie. Hier kan ons ander stemme, die stemme van ons broers en susters verneem, hulle lyding onder en interpretasie van die werklikheid, hulle wanhoop en hoop. Hier kan ons mites gerelativeer word, onthul word as presies dit wat dit is: mensgemaakte konstruksies vir ons eie wel en weë. Hier, in die kreatiewe samewerking van vele interpretasiemodelle, kan eensydige fikseringe en almagsfantasieë aan die lig gebring word. Waarlik, ons het mekaar nodig, meer as wat ons dink of sou wou toegee. Die woord van Christus in die mond van my broer en suster is tog meer werd as die woord van Christus in my hart (Bonhoeffer)!

Wat ek dus bepleit, is 'n ekumeniese hermeneutiek. As die kerk in Suid-Afrika nog enigsins ' $n$ rol wil speel in die pastorale begeleiding en sosiale terapie van 'n verwonde samelewing op pad na genesing, sal ons in die jare wat voorlê gereeld ons brille moet uitruil, en in 'n toenemende mate ons perspektiewe op die Skrif én ons Suid-Afrikaanse werklikheid met mekaar moet deel. Ons leef in 'n tyd van transisie, 'n tyd waarin ons nie oor 'n arsenaal van sekerhede beskik nie, maar wel mekaar as gawe ontvang het: "Ons het slegs die kontradiksies van ons geskiedenis, die Bybelse roetekaart en ... mekaar. Waarvan die Bybel ons verseker, is dat God tussen ons teenwoordig is en dat ons die getuienis van ryk én arm, slaaf én vryman, man én vrou, Jood én Griek nodig het as ons Hom in hierdie maalstroom wil herken" (Deist 1991:380). 


\section{BIBLIOGRAFIE}

Adonis, JC/Smit, DJ 1991. Myth versus myth. Conflicting myths in South African religious discourse on violence. Apologia Vol 6 No 2.

Barthes, R 1964. Mythen des Alltags. Frankfurt. Suhrkamp.

Bohren, R 1971. Reformatorische und Neuprotestantische Definition der Predigt. München. Kaiser.

Bohren, R 1983. Der Aufruf zur Busse. Past Th 83.

Bohren, R/Jorns, KP 1989. Die Predigtanalyse als Weg zur Predigt Tübingen. Francke Verlag.

Carroll, R 1991. Wolf in the sheepfold. The Bible as a problem for Christianity. SPCK London.

Cilliers, JH 1992. Prediking as ekklesiale diskoers: 'n ontwerp. NGTT Deel 33 No 3. 1994. Die teologiese onderbou van die prediking - 'n analise en beoordeling van Nederduitse Gereformeerde volksprediking (1960-1980). Praktiese Teologie in Suid-Afrika. 9/1, 1-13.

-1994. God vir ons. 'n Analise en beoordeling van Nederduitse Gereformeerde volksprediking (1960-1980). Kaapstad: Lux Verbi.

_ 1996. Die uitwissing van God op die kansel. Ontstellende bevindinge oor SuidAfrikaanse prediking. Kaapstad: Lux Verbi.

2000. Die genade van gehoorsaamheid. Hoe evangelies is die etiese preke wat ons in Suid-Afrika hoor? Kaapstad: Lux Verbi BM.

Deist, FE 1990. Notes on the context and hermeneutic of Afrikaner civil religion Missionalia Vol 18/1 p 124-139).

1991. Objektiewe Skrifuitleg? Kanttekeninge by Skrifuitleg in die Nederduitse gereformeerde Kerk 1930-1990 Herv. Teol Studies 47/2 p 367-385).

Greidanus, S 1970. Sola Scriptura. Problems and Principles in Preaching Historical Texts. Wedge Publishing Foundation. Toronto Canada.

Iwand, HJ 1964. Gesetz und Evangelium (in Nachgelassene Werke 4 Hg Kreck). München. Josuttis, M 1966. Gesetzlichkeit in der Predigt der Gegenwart. München.

Marsch, WD 1964. Politische Predigt zum Kriegsbeginn 1914/1 91 .5. Ev Th 14 Jahrgang. Müller, BA 1987. Tendense in Afrikaanse Godsdiens Programme. Stellenbosch. RGN Navorsingsprojek.

Müller, CFJ (red.) 1980. Vyfhonderd jaar Suid-Afrikaanse geskiedenis. Pretoria.

Pressel, W 1967. Die Kriegspredigt 1914-1918 in der evangelischen Kirche Deutschlands. Göttingen.

Richter-Böhne, A 1989. Unbekannte Schuld. Politischer Predigt unter allierter Besatzung. Stuttgart. Calwer Verlag.

SIök, J 1960. Mythos und Mythologie RGG. Band 4, 37-42. Tübingen.

Wolff, HW 1969. Jahwe und die Götter in der altestamentlichen Prophetie. Ein Beitrag zur Frage nach der Wirklichkeit Gottes und der Wirklichkeit der Welt. Ev Th 39 Jahrgang. 